\title{
SERVANT LEADERSHIP: EDUCATIONAL INSTITUTION
}

\author{
Yayan Rahayani \\ Sarjanawiyata Tamansiswa University
}

\begin{abstract}
Servant leadership was firstly introduced by Robert K. Greenleaf in his essay The servant as leader in 1970. Greenleaf had spent his life working for a telecommunication company before he eventually dedicated his life as a public teacher. He concerned about wider society and global culture. His belief is that authentic change happened only when it began in the inner solitude of single individuals. Greenleaf explains that the servant leader is servant first with the natural feeling that one wants to serve. The leader-first and the servant-first are two extreme types of leaders with the servant-first leader taking care to make sure other people's highest priority needs are being served. Following the desire to serve may be a conscious choice that brings one to aspire to lead. In educational setting, servant leadership seems to be the most compatible leadership compare to transformational and charismatic leadership. Teachers serve the need of student and in turn this will encourage students consciously to become leader for themselves to be more independent.
\end{abstract}

Keywords: Servant leadership

\section{A. Introduction}

Caring for persons, the more able and the less able serving each other, is the rock upon which a good society is built

Robert K. Greenleaf

The concept of leadership has evolved beyond the traditional perspective, which focuses on behavioral observation. Leadership was used to be observed based on organizational outcomes and performances by assessing what was 
happening in organization or workplace (Yukl \& Tracey, 1992). Not until the emergence of what so-called the "New Paradigm" of leadership approach/model that incorporates such variables as charisma, vision, and transformation into leadership discussion, the traditional approach of leadership had dominated the view since its earliest formal discussion in the 1930's. The rise of new paradigm in leadership was related to the major shift of concern from management to leadership issue among the writer due to their disappointment of situational leadership paradigm in the 1970's (Alimo-Metcalfe \& Alban-Metcalfe, 2005, pp. 51). One of the most well regarded leadership paradigm is servant leadership, which focuses on principles, beliefs and values of the leaders, and not the behavior (Farling, Stone, \& Winston, 1999, p. 53).

This essay discusses the definition, origin and development of servant leadership followed by its characteristics, strengths and weaknesses, and its application in educational institution. Conclusion will be at the last to wrap up the discussion. Arguably, servant leadership is compatible with and could be practiced in educational institution, since teachers can be seen as servant leaders in the sense that they are supposed to meet the interests and needs of students as their followers.

\section{B. Servant Leadership: Definition, Origin and Development}

Could the servant be a leader? Are servant and leader compatible? These questions always exist in discussing servant leadership because servant and leader seem to be in opposition. The term servant leadership was introduced for the first time by Robert K. Greenleaf in his essay in 1970, The servant as leader (Spears, 1995, p.2). Greenleaf was an employee at AT \& T - the big telecommunication company in the United States at that time - in the field of management, development and research after he had worked as a lineman for a while. Since then, he lectured in several major institutions such as MIT (Massachusetts Institute of Technology), Ohio University, Ford Foundation, etc. This Indiana-born expert established Center for Applied Ethics, the institution which was renamed after him since 1985 (Crippen, 2008, p. 12; Spears, 1995, p, 2). The idea of servant as a leader came up after Greenleaf finished reading a novel of Hermann Hesse's Journey of the East. The central figure in the story, Leo, who acted as a servant turned out to be the most influential person for all the crew members during the journey. The lost of the Leo's guiding and caring spirit, the groups felt into disarray and the journey was 
abandoned (Greenleaf, 1977, p. 7). The central idea of servant leadership is that "great leader must first serve others and that this simple fact is central to his or her greatness: true leadership emerges from those whose primary motivation is a desire to help others" (Spears, 1995,p.3).

In 1977, when he reached the age of 73, Greenleaf published a book Servant Leadership: A journey into the nature of legitimate power and greatness, which eventually became the model of today's servant leadership. According to Greenleaf, servant is a person who always "searching, listening, expecting that a better wheel for these times in the making" (Greenleaf, 1977, p. 9). He suggested that everyone could act as servant regardless his/his position in the organization, either "a leader or follower." Further, he explained that natural servants are:

challenging the pervasive injustice with greater force and they are taking sharper issue with the wide disparity between the quality of society they know is reasonable and possible with available resources, and on the other hand, the actual performance of the whole range of institutions that exist to serve society (Greenleaf, 1997, p. 9).

In Greenleaf's (1977) view, natural servants are persons "who understand that they are serving first." Therefore, they are more likely to "define and strive to meet the need of others that the need of person who is the leader" (p. 14). The servant as leader, Greenleaf proposed, "begins with natural feeling that one wants to serve, to serve first' (cited in Spears, 1995, p. 4). Servant leadership views leaders as servants of their followers. This type of leadership places the interests and needs of followers before the leaders, focuses on personal development and empowerment of followers. The leaders are facilitators for followers to achieve their shared vision.

Although Greenleaf was the one who developed the concept of leadership, he did not provide an exact definition of servant leadership. Rather, he emphasized on specific behavior of a servant leader and his/her influence on the followers. The founder of servant leadership, however, dated back in the work of Jesus Christ written in the Bible. From the story told in the Bible, Jesus was a model of a servant for his followers. He was unaware that he had practiced servant leadership throughout his life. Even, he did not suppose that his life would be the model that has been pervasively practiced in across types of institution and organization (Sendjaya \& Sarros, 2002, p. 58). This practice has been acknowledged and practiced for long time. It is not a recipe found in a cook book that can work 
instantly in a short term period. Instead, it is a hard work that requires a long term and transformational approach. It is a way of being that has the potential to create a positive change in society.

In its development, servant leadership has long been considered to have a close relation with such other types of leadership as charismatic and transformational leadership. Sendjaya \& Sarros (2002) noted that both servant and transformational leadership are based on the study of charisma. The earliest empirical work of charisma could be traced back in the work of Max Weber, when he conducted a study of Greek word of charisma. Weber postulated that charisma is "a quality of an individual personality by virtue of which he [the leader] is set apart from ordinary men and treated as endowed with supernatural, superhuman, or at least specifically exceptional qualities" (p. 61). The leader is a person who exercises power through the identification and belief of follower in leader's personality (Smith, Montagno, \& Kuzmenko, 2004, p. 81).

In the study of comparing transformational leadership, personal charisma, Weberian charisma and servant leadership, Graham (1991) suggested that charisma is a foundation of transformational and servant leadership model. She argued that both transformational and servant leadership are moral and inspirational. However, she also pointed out that servant leadership allows more room for passive followers (cited in Smith, et al, 2004: p. 81). However, there are two distinguished characters of servant leadership that exceed transformational leadership: (1) recognizing the leader's social responsibility to help the marginalized society; and (2) dedicating to the follower's need and interest, as opposed to the need of leaders and organizations (Sendjaya \& Sarros, p. 62). This is needless to say that servant leadership is a part of the "new paradigm" of leadership, since it goes beyond what is happening in organization (i.e. organizational outcome and people behavior). Rather, it focuses on leader's principle, belief and personalities.

\section{Characteristics of Servant Leadership}

Servant leadership deals with the reality of power in everyday life, its legitimacy, the ethical restraints upon it and the beneficial results that can be attained through the appropriate use of power. 
Transition to a culture of servant leadership requires time for the development of necessary feature or quality for a servant leader (Crippen, 2004, p. 13). Spears (2005) identified ten characteristics of servant leadership: listening, empathy, healing, awareness, persuasion, conceptualization, foresight, stewardship, commitment, and building community. Firstly, listening intently to other is one of important skills in implementing servant leadership. Listening refers to a deep commitment to listen to others (Crippen, 2004, p. 13). Listening includes both something that are being said and not being said (Frick \& Spears, 1996, pp. 139-140). Listening means stay in touch with someone's inner voice and try to understand one's body, spirit, and mind. Thus, listening as a part of communication is essential to the growth of servant leader. De Pree (1989) argued that the best communication forces you to listen (pp. 12-13). Secondly, empathy as another characteristic of servant leadership refers to understanding others due to people need to be accepted and recognized for their special and uniqueness (Spears, 1995, p. 5). Greenleaf(1977) stated that empathy means "the imaginative projection of one's own consciousness into another being" (p. 20). Spears (1995) said that the most successful servant leader is the one who has skilled as empathetic listener (p. 5). Healing reflects a powerful force for transformation and integration (Spears, 1995, p. 5). There are a lot of people who have broken spirits and have suffered from psychological symptoms; servant leader recognizes that he/she has an opportunity to help them out of problems. In addition to that, general awareness, particularly self awareness strengthens a servant leader. Greenleaf explains that "awareness is not giver solace, it is just the opposite; it is a disturber and awakener; so, able leaders are usually sharply awake and reasonably disturbed" (cited in Spears, 1995, p. 5). Awareness can also be seen in the illustration of people who are opening the door widely. In other words, opening the perception in order to make others enable to get more from what is available inside (Greenleaf, 1977, p. 27).

Other characteristics of servant leader are persuasion and conceptualization. Persuasion refers to "a reliance upon persuasion, rather than positional authority, in making decision within the organization"' (Spears, 1995, p. 5). Leadership by persuasion leads to the change by convincement rather than coercion (Greenleaf, 1977, p. 30). The assumption to use persuasion better for servant leader rather that coercion is rooted in the beliefs of the religious Society of Friends (Quakers) (Greenleaf, 1977, pp. 29-30). The persuasion process can be practiced by servant leader easily because of his ability to build a consensus within the groups. Likewise, servant leader should have ability to look at a problem inside the 
organization from a conceptualization perspective. Conceptualization means "one must think beyond day-to-day realities" (spears, 1995, p. 6). The ability to foresee what would happen based in current situation requires continuous practices.

The ability to predict the future is hard to define as one knows something when he sees it, but it can be identified. Thus, foresight is one characteristic that enable servant leader to understand the lessons from past, the present realities, and predict the future. Spears (1995) said that this characteristic relies much on the intuitive mind (p. 6). Furthermore, it is necessary to explain the stewardship as it is included as one of characteristics of servant leadership. Block (1993) described stewardship as "holding something in trust for another." Spears (1995) argued that servant leadership is similar to stewardship in term of "assumes first and foremost a commitment to serve the needs of others (p. 7). It is also important for servant leader to have a commitment to the growth of people. A servant leader, who is committed to the individual growth of human beings will do everything he/she can to help others. Lastly, building community can also be included as an important aspect of servant leadership. By building a community, servant leader can have more influence toward others and his/her leadership style can be more pervasive.

Spears (1995) argued that the generational changes will lead to the change of perception and cause a certain sense of loss. So the servant leader seeks to identify some means and tools to build community. He pointed out that "true community can be created among those who work in business and other institutions" (p. 7). There are three approaches to build community such as backing through service to community, investing financially into community, and caring about one's community (Crippen, 2004, p. 14). Pinchot argues that the person who gives contribution or invests to the community has the highest status (cited in Hesselbein, Goldsmith, Beckhard \& Schubert, 1998).

After reviewing some characteristics of servant leadership, we can propose at least one example of leader/person that has a character as a servant leader. Mother Theresa, for instance, is one clear example of person who has some characteristic that qualify her to be a servant leader. She had dedicated her life to take care of others. She always put other people's need and interest over herself. Her care and empathy to other people, her awareness of building a caring community has always accompanied her journey. Despite the fact of her religious belief, her dedication to humanity and marginalized society remained unquestioned. 


\section{Strength and Weaknesses of Servant Leadership}

In observing the character of servant leadership, we can assume that servant leadership has some distinctive features, identified as strengths compared to other leadership style. Servant leadership emphasizes on collaboration, trust, empathy, and ethical use of power (Greenleaf, 2003, p. 23). Supported by the dedication to work for the benefit of others, the leaders are willing to collaborate with other people (leaders and followers), trust them, put the empathy to the marginalized people and they are supposed to be ethical in a use of power they might have. It is common in servant leadership practice that ethical consideration is a prime consideration in exercising the power, because the "do no harm" or caring principle to the followers is compatible with the principle of benefiting others. In other words, satisfaction of others is the priority.

Intellectual stimulation through encouragement, affirmation and initiative thinking seems to be the next strength of servant leadership. This stimulation refers to developing people's potential and facilitating their personal growth. A servant leader would encourage followers to learn and would support them by providing chances to obtain and apply knowledge and skills in organization for the sake of obtaining new level of responsibility (Smith et al., 2004, p. 84). Intellectual stimulation leads to other strength of servant leadership, i.e. transformational approach to life and work (Sendjaya \& Sarros, 2002, p. 62). It means that everything happening in the organizations is being transformed across the level and status. Although it takes a fair amount of time, the relationship among elements within the organization is considerably close. The well established interpersonal relationship is another strong feature of servant leadership because of the trust, shared responsibility and most importantly the equality principle. It seems to be no hierarchical structure within servant leadership organization. Smith et al. (2004) argued that a servant leader views leadership as an opportunity to serve others, not as a status or position, not a power over others (p. 82). A servant leader considers all members as leaders who can take charge in certain point of time. Shared responsibility supports personal involvement and teamwork.

However, servant leadership could be regarded as a "soft" leadership style by others. It is due to the principle of listening, caring, empathy, and persuasion. When the situation requires leaders to be firm and directive, servant leaders tend to step back and listen to others' opinion and ideas. It could slow down a decision making process and its implementation. This is the reason why sometimes this type 
of leadership is not compatible with the organization where the firm and more directive leadership are needed. Since it is not a quick tip for solution, servant leadership needs time to be practiced and exercised to have effect on the followers and members. Wong and Page (2003) added that servant leadership is based on theocracy and it could lead to the abuse of authority if the leaders are not accountable enough to hold the leadership position.

\section{E. Servant Leadership in Educational Institution}

With regard to the implementation of servant leadership in a school context, Greenleaf (2003) concerned with three things: (1) it is imperative to offer explicit preparation for leadership opportunity to those who have potential; (2) general attitude of educators towards social mobility; and (3) the state of confusion regarding the teaching of values. He further suggested that students should be regarded as leaders (to serve the community where they live in) and followers (to have their needs met by the teachers).

Jennings and Stahl-Wert (2003) as cited in Bowman (2005) proposed five pragmatic principles of servant leadership in contemporary educational setting. First is to serve first and lead secondly. Inspiring is more important and useful than controlling and managing the students. Serving students' need and interests is the first and foremost priority for teachers. Second is unraveling the strengths, talents and passion of those who are served. It means that teachers should help the students out" of their problems and mentor them towards the solution. Third is establishing high standards of performance. Establishing standards is one form of intellectual stimulation that could encourage personal development and growth. Students are challenged to meet the standard in order to be able to get through their education. The fourth is addressing the weaknesses and building the strengths. The fifth is putting oneself at the bottom of pyramid so that he/she could unleash the energy, excitement and talents of served-community (Bowman, 2005, pp. 257-259).

Needless to say, this kind of leadership will not bring the organization beyond its profit and positive work attitude. Meanwhile, an educational institution should bring about social change and social justice in society. Ideally, educationaI institutions should go beyond restructuring society but making significant positive changes, particularly to the population served. These objectives can be gained through collaborative works among people within organization. 
In accordance with the transformational leadership style that incorporates the notion of charismatic leader, schools seem to have more opportunities and resources to exercise this type of leadership. However, the implementation of transformational leadership style with a means of charisma should take the followers' position into account in order not to cause dependency to the followers. The implementation of servant leadership, on the other hand, is very obvious in the sense that the school is trying to build community within and outside the school. Its commitment to the growth of students is shown in programming and activities that use integrative approach in education.

\section{F. Conclusion}

This paper indicates the distinctive characteristics of servant leader lie in their primary intention and self concept. Primary intention of servant leader is to serve the population and put others' need over their own. Greenleaf (1977) asserted that servant is a person who understands and tries the meet the highest priority need of others ( $p .14)$. Leader is one who goes ahead to lead the way and has influence (p. 287). Servant leader is a leader who put others' need, aspirations, and interest over their own. Some argue that the servant leadership is a form of transformational leadership that based on the application of charisma (Smith et al., 2005). It is interesting to note that servant leadership characteristics can be found in transformational and charismatic leadership. Therefore, servant leadership could be applied in any given settings, including in educational institution.

\section{REFERENCES}

Alimo-Metcalfe, B, \& Alban-Metcalfe, J. (2005). Leadership: Time for a new direction. Leadership, 1 (1):51-71.

Bowman, R. F. (2005). Teacher as servant leader. The Clearing House, 78 (6): 257 259.

Crippen, C. (2004). Servant-leadership as an effective model for educational leadership and management. Management in Education, 18 (5): 11-16.

De Pree, M. (1989). Leadeship in art. New York: Dell Publishing Group. 
Farling, M. L., Stone, A. G., \& Winston, B. E. (1999). Servant leadership: setting the stage for empirical research. The Journal of Leadership Studies, 6 (1/2):49-72.

Frick, D., \& Spears, L. (eds.). (1996). The private writings of Robert K. Greenleaf: On becoming a servant leader. San Francisco: Jossey-Bass

Graham, J. W. (1991). Servant leadership in organizations: Inspirational and moral. Leadership Quarterly, 2 (2): 105-119.

Greenleaf, R. K. (2003). The servant leader within: A transformative path. New Jersey: Paulist Press.

Greenleaf, R. K. (1977). Servant leadership: A journey into nature of legitimate power and greatness. New York: Paulist Press.

Hesselbein, F., Goldsmith, M., Beckhard, R., \& Schubert, R. (ed) (1998). Community for the future. New York: The Peter F. Drucker Foundation.

Jennings, K., \& Stahl-Wert, J. (2003). The serving leader. San Francisco: BerretKoehler.

Peter, B. (1993). Stewardship. San Francisco: Berrett-Koehler Publishers.

Pinchot, G. (1998). Building community in the workplace. In F Hesselbein, M. Goldsmith, R. Beckhard, \& R. Schubert, (ed) (1998). Community for the future. New York: The PeterF. Drucker Foundation.

Sendjaya, S., \& Sarros, J. C. (2002). Servant leadership: Its origin, development, and application in organizations. Journal of leadership \& organizational studies, 9 (2): 57-64.

Smith, B. N., Montagno, R. V., \& Kuzmeko, T. (2004). Transformational ad servant leadership: Content and contextual comparisons. Journal of leadership and organizational studies, 10 (4): 80-91.

Spears, L. (ed.) (1995). Introduction: Servant-leadership and the Greenleaf legacy. In R. K. Greenleaf, M. S. Peck, P. Senge, A. McGee-Cooper, S. M. Bethel, \& W. Kiechel III, Reflection on leadership: How Robert $K$. Greenleaf's theory of servant-leadership influenced today's top management thinkers. Brisbane: John Wiley \& Son, Inc., pp. 1-14. 
Wong, P. T. P., \& Page, D. (2003). A conceptual framework for measuring servant leadership. In S.Adjibolosso (ed.). The human factor in shaping the course of history and development. Boston, MA: University Press of America.

Yukl, G., \& Tracey, J. B. (1992). Consequences of influence tactics used with subordinates, peers, and the boss. Journal of applied psychology, 77 (4): 525-535. 